The Philosophical Journal of Conflict and Violence

Vol. III, Issue $1 / 2019$

(C) The Authors 2019

Available online at http://trivent-publishing.eu/

\title{
Of Violence and Intimacy: the Shame of Loving and Being Loved
}

\author{
Lou-Marie Kruger \\ Department of Psychology, Stellenbosch University \\ South Africa, lkrug@sun.ac.za
}

\begin{abstract}
This paper explores violence in intimate relationships in one low-income community in the Western Cape, South Africa. In this community most intimate relationships (including parentchild, intimate partner relationships and friendships) seem to be characterized by anger, rage and also violence. In our analysis we discuss how the concepts of shame, guilt and the compulsion to repeat can serve to illuminate the seemingly inevitable link between violence and care in this specific community. It also seems that contextual factors such as class, gender and race shape not only the form violence assumes, but also to whom it is directed. While we pay attention to the material and ideological conditions that shape the lives of individual storytellers, we also focus on the ways in which violence is represented in the individual stories.
\end{abstract}

Keywords: anger, violence, intimacy, love, care, shame, guilt, intimate relationships, motherdaughter relationship, class, gender, race

DOI: 10.22618/TP.PJCV.20193.1.192005

The PJCV Journal is published by Trivent Publishing

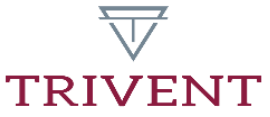

This is an Open Access article distributed in accordance with the Creative Commons Attribution Non Commercial (CC$B Y-N C-N D$ 4.0) license, which permits others to copy or share the article, provided original work is properly cited and that this is not done for commercial purposes. Users may not remix, transform, or build upon the material and may not distribute the modified material (bttp:/ / creativecommons.org/licenses/by-nc/4.0/) 


\title{
Of Violence and Intimacy: the Shame of Loving and Being Loved
}

\author{
Lou-Marie Kruger \\ Department of Psychology, Stellenbosch University \\ South Africa, lkrug@sun.ac.za
}

\begin{abstract}
This paper explores violence in intimate relationships in one low-income community in the Western Cape, South Africa. In this community most intimate relationships (including parentchild, intimate partner relationships and friendships) seem to be characterized by anger, rage and also violence. In our analysis we discuss how the concepts of shame, guilt and the compulsion to repeat can serve to illuminate the seemingly inevitable link between violence and care in this specific community. It also seems that contextual factors such as class, gender and race shape not only the form violence assumes, but also to whom it is directed. While we pay attention to the material and ideological conditions that shape the lives of individual storytellers, we also focus on the ways in which violence is represented in the individual stories.
\end{abstract}

Keywords: anger, violence, intimacy, love, care, shame, guilt, intimate relationships, motherdaughter relationship, class, gender, race

It is bad to live without a hell: aren't we able to reconstruct it? (Pablo Neruda1)

I am, of course, speaking of the way of life which makes love the centre of everything, which looks for all satisfaction in loving and being loved...It is that we are never so defenceless against suffering as when we love, never so helplessly unhappy as when we have lost our love object or its love. (Sigmund Freud ${ }^{2}$ )

In a murderous time

the heart breaks and breaks

and lives by breaking.

It is necessary to go

through dark and deeper dark

and not to turn.

I am looking for the trail.

(Stanley Kunitz ${ }^{3}$ )

June. Early winter's day. Mahler and the mountains in my car. The fields are white with varklelies (lieterally translated the lilies of pigs, arum lilies). Muddy parking lot. Crisp air. My morning is almost fully booked. Some old cases. A few new ones.

\footnotetext{
1 P Neruda, The Book of Questions (Washington, DC: Copper Canyon Press, 1974), 18.

2 Peter Gay, Freud. A Life for Our Time (New York: Doubleday, 1988), 733.

${ }^{3}$ Stanley Kunnitz, The Poems of Stanley Kunnitz 1928-1978 (New York: Little, Brown and Company, 1978).
} 
Patricia Solms is my first case of the day. She and her husband recently lost their ten-yearold daughter daughter to cancer. Five years ago their baby son died of meningitis. Pregnant Desire Williams is fourteen years old, severely depressed and wants an abortion. The pastor at her church has forbidden her to get one. Disconcertedly, ten-year-old Desmonique Pieterse, molested by her father, does not show for her weekly session. She is still living with her mother, her father (that father) and younger brother in one room in her uncle's house. Paulette Verdriet is twelve years old and lives with her mother, father and two sisters in a shack. Her father drinks every day, frequents the smokkelhuis (illegal tavern). He has a girlfriend. He screams at Paulette's mother: 'Jou nai, jou ma se poes. Ek maak jou vrek. (You fuck, your mother's cunt. I will kill you)'. Her foster sister of two died in a shack fire the week before. Paulette heard the crying and the eventual silence. She has bad dreams.

Both nurses also have new patients for me. The first case is a sixteen-year-old boy who is afraid of his anger: he is angry with his alcoholic father who almost killed his mother and is now in jail. The other is a sixteen-year-old boy who got two girls pregnant. 'Is there nothing to do in this town, but bonking? Why don't you rather kick a ball?' says the nurse when she introduces me to him.

On the desk, next to me, is an open box of condoms and a life-size erect wooden penis, used for sex education classes. In small print on the penis it says, 'Only for external use'. The grains on the wood of the penis look like veins. I struggle to focus on the boy.

Delize Plesier is my last patient of the day. I am seeing her for the third time. She is a thirty-three-year old seasonal farmworker with Grade 7 education. At the time of the session, she has a fourteen-year old boy, a nine-year old girl and six months old baby-girl. The protestant church group that she joined just before the baby's birth insisted that Delize marry her long-time partner, Piet. Before that they had been living together for about thirteen years. The couple lives with the three children and Delize's mother on a farm in a small house with two rooms, a kitchen, a small living area and a bathroom. In the first session Delize already told me that her husband is a heavy drinker, a womanizer and that he beats her regularly. She is soft-spoken and seems very sad.

Delize starts the session, expressing concern that she always talks about herself when she sees me. 'But I want to ask,' she says shyly, 'is it good should I... It feels to me that I complain that I only complain to you about my problems. Can I talk about them? It feels to me, yes, as if it is about my problems that I come and talk about and that is not the actual thing that you really want to talk about? If maybe it is only about the baby?'

I tell her that the sessions really are about her. Reassured for the moment, she continues. 'Yes, there were many times that I thought, wow, with whom. Is there not someone to whom I can open my heart? Can take my problems to? Because you can't with everyone.'

Now she goes on to talk about her husband, Piet: his womanizing, his drinking, his spending, his sexual demands and his violence. She also reveals that she is worried about contracting diseases, because Piet sleeps with women who are rumoured to have diseases: 'Like the two of us we sleep together, I'm careful for that. I'm scared. Maybe I can't get the germ, but my child can get a germ by his sleeping around.'

Her biggest worry is about her transmitting a virus to her baby through breast-feeding. I ask her whether she still is intimate with her husband? 'Ja,' she says, 'nie eintlik nie (not really).' She pauses frequently as she speaks. 'It feels as if when he moves in that direction I get grillings (shudders) through my body. I don't know whether he's clean or not. Because a man that walks around so much at night, you know what type of person he is. Because the actual thing is he doesn't come for me he doesn't act correctly like other men react to their their wives. But with other women as we now work, I can see in the house he won't just talk to me, as soon as he [sees] other women outside the door ... then he enjoys talking to them. Laughs and talks. Now when we maybe have an argument here in the house and I tell him those 
things he will always tell me I'm jealous. Then I tell him but I'm not jealous. It just things that hurt me, I see how you talk nicely to other vroumense (derogatory word for "women") and when they ask you to do something you'll quickly do it for them, but for me you'll never if I ask you you'll never do it, or you won't give a good face.'

The heart breaks and breaks and lives by breaking.

Delize now speaks more slowly, with longer pauses. 'The attitude he has in the house is not that good towards me or my children. Actually my biggest worry is about my kids. See, it seems he doesn't give them attention, he doesn't give them love. The only thing he does is to raas (scold) and skeree (shout) at them. Or they must now sommer do a job like he wants now.'

She feels lonely and frustrated as a parent and is aware that she tends to take out this frustration on her children. 'At the Apostolic Church they mos say you, like the teachers now teach the Sunday school kids that you may not smack your child. You must take the child then you must make him sit down and talk nicely. So that he can understand you, because if you raas and skree at her then you just make the child worse than he is. The children are so stubborn. Many times I sommer feel like taking a thing and smacking the child, but then it comes to me again, it's wrong to smack my child. Because I take it, the problem lies with us as parents. Now if the father can just support me with the children then things will come right. When he is sober, not when he is drunk. Now the moment I need him with the children then he isn't there.'

Delize tells met that she recently had a violent confrontation with her husband. Telling this story, her demeanour is still sad rather than angry. Her speech is slow, not belligerent at all. 'Actually,' she says, 'we had an ugly confrontation last week and I almost had him burned, burned with boiling water. He is, as I have said before, he loves women on the other side of the doors. He communicates with women a lot, he brings them home and they drink together. I am the quiet kind; I don't really talk at that moment. It feels bad to me to make a scandal or fuss at that moment. Now if they are gone then I will talk to him, but I have not talked to him. Now his male friends also come drinking with him. If they there then it is not good or he makes them my men. And then his nasty manners start. At such time I can do almost nothing in the house. I have to be around him. In his eyes. But I say it is because he is that type of person and then he looks at me with that type of attention. We have come a long way. He knows, he knows me, I am not that type of person doing bad things, but now he thinks, because he himself stands behind the door, I do such things. He then lost it totally and while I was writing up my groceries for the Friday and Saturday I felt him hitting me on my mouth, my jaw hurt. Then I thought there is only one way, because before that I boiled water for the child's bottle so I took the water and he realized and he followed me and he took my chair to throw it at me, but then I took the kettle just like that with the water and I gave him a shot of the water. That water then broke him down. He had a fright and he made a noise so that my sister-in-law came running. Then I told her that I just burned him. That was the only way in which I could defend myself. But he did not really burn, the water was not of a strong heat, because then he would have had blisters or his skin would have burned. He only got a fright. But now I am quite cautious, now after I did this. I think that he can try it with me too and then the water is boiling. And maybe I have the child on my arm. But I really don't know what to do with the man.'

She talks about the church and her frustration with not being able to participate fully in church activities, as her husband does not support her. 'He should be working with me, but he doesn't. It feels as if there is very little interest from his side in me and my children. I accept but I accept but it has to come. Many days I think this is probably the way it should be. They say if there is not a struggle there is not victory.'

When asked about the possibility of leaving her husband (a fantasy that she expressed in a previous session), Delize says that 'the church people, the priests, they say if you are married, 
only death, only death can set us apart. It does not exist with them the possibility that you can get divorced, then death should separate you. Now they say, if they pray, they pray the Lord should take that person away so that I can get rid of him. Look he is, they say he stands in my way. I want to continue with things, the work of the Lord, but he stands in my way.'

Her disillusionment and sadness are palpable, but also her resignation. 'And the things, I now thought the man will now improve after he had a little baby, because he has mos now already seen the child. The child is there, so he must now mos improve. But nothing changed the time in the hospital was, the interest, the little interest that he had and so on. Nothing went well in the time I was in the hospital, where he now had to stand in my place for me.'

Then, suddenly, startled, interrupting her own story, she looks at me, panicky. 'As I sit here now, the worry grabs me, what's the time? One o'clock?'

'Yes,' I say. 'It is one o'clock. Are you in a hurry?' 'Ja,' she says, 'because he can now also maybe get difficult, and I didn't really leave them something to eat this morning. And he is mos now so, I must put everything in his hands myself.'

I apologize for not having watched the time. We agree about a next appointment and she leaves in a rush, but still moving slowly, with hanging shoulders. Her clothes are loose on her slight body. 'The breast-feeding takes its toll,' she said earlier...

Outside it is bright and cold. The streets smell like rain and school children. The children wear track suits and walk and play and walk and play on the wet tar road outside the clinic. The dogs, as always, are lean and many.

I stop to pick some arum lilies. It is against the law. It starts raining. I drive too fast. I want to get home. Get the lilies in water.

\section{Guilty and powerbut power}

On this day in the clinic I am confronted with family and certainly how "an unhappy family is unhappy after its own fashion": 4 there are two dead children, a raping father, a pregnant school girl, a devastating household fire, a fornicating fertile schoolboy, a boy furious with his father. However, somehow, on this day it is Delize that stays with me while I place the glass vase with arum lilies next to the clock and the tissue box of my private practice office. Gentle Delize who stays and stays while her heart breaks and breaks, her silent rage overshadowed by the the longing to be heard and the hope for change. Through dark and deeper dark, I am aware of her exaggerated sense of responsibility and her almost invisible power.

I think of Victoria Sweet and her book God's Hotel. A doctor, a hospital, and a pilgrimage to the heart of medicine: ${ }^{5}$

When I looked into Mr. Hickman's open wound and saw that, exposed and vulnerable, nestled in the hollow that the surgeons had created, was Mr. Hickman's beating heart.

It was extraordinary.

I could see the fine, delicate film of the pericardial sac glisten as it pulsed and caught the light. Woven through it - I could just make out - were tiny veins and arteries. It was so alive, that beating heart! It was as alive as Mr. Baker's body at my first autopsy had been dead. ${ }^{6}$

So many broken hearts in the valley.

The arteries of the broken heart remind me of the arteries of the wooden penis on the desk of the consulting office of the clinic office. 'Wat maak bierdie houtpiel bier? (What is this wooden cock doing here?)' one of the so-called bonking boys said angrily after being ushered

\footnotetext{
${ }^{4}$ Leo Tolstoy, Anna Karenina (Moscow: The Russian Messenger, 1877), 13.

${ }^{5}$ Of this book Oliver Sacks said, "Required reading for anyone interested in the "businesses of health care - and especially those interested in the humanity of health care."

6 Victoria. Sweet, God's Hotel: A Doctor, a Hospital, and a Pilgrimage to the Heart of Medicine (Riverhead Books, 2012), 16.
} 
in by the nurse. 'I can't concentrate with that here.' Remembering this, defensively distracted once again, I google "arteries of the penis" and find out that when something is wrong with the arteries of the penis, it typically implies problems with arteries of the heart. The penis, the internet site says, is like a barometer, a canary in the coal mine, for impending problems in the coronary arteries. ${ }^{7}$

'Kanarie. Klikvoëltjie (Canary, tell-tale),' says my friend Pieter when I tell him the story.

Delize began her session by apologizing to me for talking too much about herself. She ends the session, realizing that she might be late for making her husband his lunch, worried that he will be upset. I apologize for not having watched the time. I feel terrible when I rush back to my to my private practice on the other side of the mountain. I have taken on her guilty sense of responsibility. I feel worse for picking the arum lilies. A cheap and easy escape from my middle-class guilt and the pain.

As a psychotherapist I know that the feelings that I have about patients after sessions often is my most important source of information about the patient. We call it countertransference. ${ }^{8}$

Delize, like many women in the valley (and elsewhere), endures a violent relationship, ${ }^{9}$ seemingly selfless in her submission and suffering. She is hurt by her husband's betrayal and

\footnotetext{
7 Paolo Capogrosso et al., "One Patient Out of Four with Newly Diagnosed Erectile Dysfunction Is a Young Man-Worrisome Picture from the Everyday Clinical Practice," The Journal of Sexual Medicine 10, no. 7 (July 2013): 1833-41, https://doi.org/10.1111/jsm.12179.

8 D J Wallin, Attachment and Psychotherapy (New York, New York: Guilford, 2007), 259.
}

Wallin further states:

While we listen to the patient's words and respond with words of our own, we need to pay as much, if not more attention to the emotional, relation, and visceral/somatic undercurrents that shape the verbal exchange. The words, in their own right, may or may not convey significant meaning. The implicit, nonverbal subtext almost always does. It is the feeling of what happens here - the sense of what is actually going on in the therapeutic relationship - that can lead us to what is most immediately salient both in the patient's experience and in the interactions we co-created.

${ }^{9}$ Intimate Partner Violence (IPV) is one of the most common forms of violence experienced by South African women (D. Kaminer et al., "Risk for Post-Traumatic Stress Disorder Associated with Different Forms of Interpersonal Violence in South Africa," Social Science \& Medicine 67 (2008): 1589-95; L. Vetten, "Rape and other forms of sexual violence in South Africa," Institute for Security Studies, Policy Brief 72 (2014)). Studies have consistently found that more than half of female homicide deaths are caused by intimate male partners (a phenomenon known as 'intimate femicide'), making it the leading cause of female homicides in South Africa (N. Abrahams et al., "Every eight hours: Intimate femicide in South Africa 10 years later," South African Medical Research Council Research Brief (2012)). One research study suggests that a woman dies every six hours at the hands of an intimate partner ((N. Abrahams et al., "Every eight hours: Intimate femicide in South Africa 10 years later," South African Medical Research Council Research Brief (2012)). Whilst homicide rates have reportedly declined, recently intimate femicide appears disproportionately resistant to change, and rape homicides have increased (L. Vetten, "Rape and other forms of sexual violence in South Africa," Institute for Security Studies, Policy Brief 72 (2014)). It has been said that violence against women and girls (including domestic violence, rape, sexual assault, child sexual attack, witchcraft harassment murders, sexual harassment, and intimate femicide) creates "a deeply insecure environment for South African girls and women".

IPV exposes women to severe physical and psychological detriments, which have been widely documented both globally (M. Black, "Intimate Partner Violence and Adverse Health Consequences: Implications for Clinicians," American Journal of Lifestyle Medicine 5 (2011): 428-439; F. Boonzaier, “'If the man says you must sit, then you must sit': The relational construction of woman abuse: Gender, subjectivity and violence" Feminism and Psychology 18 (2008): 183-206; J. Crofford, "Violence, stress, and somatic syndromes," Trauma Violence Abuse 8 (2007): 299-313; B. Dekel and M. Andipatin, “Abused women's 
understandings of intimate partner violence and the link to intimate femicide," Forum Qualitative Sozialforschung 17 (2016): 1-30; M. Johnson and K. Ferraro, "Research on Domestic Violence in the 1990s: Making Distinctions," Journal of Marriage and Family 62 (2000): 948-963; A. Towns and P. Adams, "Staying quiet or getting out: Some ideological dilemmas faced by women who experience violence from male partners," British Journal of Social Psychology 48 (2009): 735-754; N. Abrahams et al., "Every eight hours: Intimate femicide in South Africa 10 years later," South African Medical Research Council, Research Brief (2012)) and in the South African context (J. Gass et al., "Gender differences in risk for intimate partner violence among South African adults," Journal of Interpersonal Violence 26 (2011): 2764-2789; Peltzer et al. 2013; A. Marais, "A narrative analysis of young people's talk of intimate partner violence," Thesis, University of Cape Town (2009); K.M. Jack, "Lived experiences of women staying in physically abusive relationships," Thesis, University of South Africa (2014)). The impact of intimate partner violence has resulted in women suffering from long-term psychological reactions (e.g. PTSD and depression) in addition to the physical injuries sustained from the abuse (A. Marais, "A narrative analysis of young people's talk of intimate partner violence," Thesis, University of Cape Town (2009); M. Mechanic, T. Weaver and P. Resick, "Mental health consequences of intimate partner abuse: A multidimensional assessment of four different forms of abuse," Violence Against Women 14 (2008): 634-654; M. Scheffer Lindgren and B. Renck, "Intimate partner violence and the leaving process: Interviews with abused women," International Journal of Qualitative Studies on Health and Well-being 3 (2008): 113-124; B. Dekel and M. Andipatin, "Abused women's understandings of intimate partner violence and the link to intimate femicide," Forum Qualitative Sozialforschung 17 (2016): 1-30). Regardless of the destructive impact of intimate partner violence on women, research in South Africa and elsewhere suggests that women often stay in abusive relationships (K. Bell and A. Naugle, "Intimate partner violence theoretical considerations: Moving towards a contextual framework," Clinical Psychology Review 28 (2008): 1096-1107; S. Hayes and S. Jeffries, "Why do they Keep Going Back? Exploring Women's Discursive Experiences of Intimate Partner Violence," International Journal of Criminology and Sociology 2 (2013): 57-71; S. Hayes, "The Big Question: Why women stay in abusive relationships,” RPI Conference, Hobart (2015); K.M. Jack, "Lived experiences of women staying in physically abusive relationships," Thesis, University of South Africa (2014); A. Marais, "A narrative analysis of young people's talk of intimate partner violence," Thesis, University of Cape Town (2009); T. Sideris, "Intimate partner violence in post-apartheid South Africa: Psychoanalytic insights and dilemmas," in Psychodynamic Psychotherapy in South Africa: Contexts, Theories and Applications, eds. Cora Smith, Glenys Lobban \& Michael O'Laughlin (Johannesburg: Wits University Press, 2013), 169-193). It is estimated that a woman leaves her abusive partner between five to seven times before she leaves for the final time, or is killed (V. Handsel, "Psychological Variables in Battered Women's Stay/Leave Decisions: Risk-Taking, Perceived Control, and Optimistic Bias," Thesis, University of North Carolina Wilmington (2007)). Even when they do seek help, more than 50\% of women return to their partners after interventions (J. Seeley and C. Plunkett, "Women and Domestic Violence: Standards for Counselling Practice," The Salvation Army Crisis Service (2002); E. Stark and A. Flitcraft, "Killing the Beast within: Woman Battering and Female Suicidality," International Journal of Health Services 25 (1995): 43-64; M. Strube and L. Barbour, "The Decision to Leave an Abusive Relationship: Economic Dependence and Psychological Commitment," Journal of Marriage and the Family 45 (1983): 785-793)). Often upon the return of the women to their partners they face even more severe abuse (K.M. Jack, "Lived experiences of women staying in physically abusive relationships," Thesis, University of South Africa (2014)). S. Matthews et al. ("Every six hours a woman is killed by her intimate partner: A National Study of Female Homicide in South Africa," South African Medical Research Council (2004)) has reported that the most volatile period for a woman in a violent relationship is prior to her leaving that relationship. Furthermore, Margi Laird McCue ("Domestic violence: a reference bandbook" (Santa Barbara: ABC-CLIO, 2008) has found that women who have separated from their violent partners are fourteen times more likely to report incidences of abuse by a spouse or ex-spouse.

Several international (L. Kiss et al., "Gender-based violence and socioeconomic inequalities: Does living in more deprived neighbourhoods increase women's risk of intimate partner violence?," Social Science and Medicine 74 (2012): 1172-1179; A. Peterman, J. Bleck and T. Palermo, "Age and Intimate Partner Violence: An Analysis of Global Trends Among Women Experiencing Victimization in 30 Developing Countries," Journal of Adolescent Health 57 (2015): 624-630; E. Rose, "A feminist reconceptualisation of intimate partner violence against women: A crime against humanity and a state crime," Women's Studies 
abuse, but also protests against her fate (usually silently, but in this case with a boiling kettle of water), hoping for an eventual good outcome. She knows that the suffering endured is unjust and undeserved, but endures it in the hope, conscious or unconscious, for some eventual greater good. ${ }^{10}$

'I have to put everything in his hands myself.'

'There is no victory without struggle.'

'Only death can set us apart.'

'Then I took the kettle just like that...'

Despite the occasional fighting back (maybe unconsciously nudging fate in the direction of death and victory), in general, Delize remains faithful to the cultural and religious rules of the nuclear family, rules that compel her to stay, to serve, to be submissive, and to endure.

How can terrible aspects of experience be incorporated into daily life and kept alive when people need to survive and tend to their ordinary activities? Those aspects of unbearable reality tend to be banished...the need for loved ones to stay close is so deep, and the need to maintain the status quo so ingrained...the hope of change and feelings of forgiveness are powerful forces that lead people to remain in dangerous places, with violent partners, working frantically to make them safer or trying not to provoke their rage. ${ }^{11}$

Delize's staying in a relationship where her role is that of service, submission and selflessness, in her eyes, is neither in vain, nor pointless. She tolerates the suffering both to accomplish a goal (to maintain the relationship, to be a good woman) and to avert the more painful eventuality (to lose the relationship, to be a bad woman). In her eyes her suffering is thus justified. ${ }^{12}$

Delize's husband, Piet, when we interview him, is very clear that womanhood is synonymous with swaarkry (suffering) and care. 'No, when I found out I'm a man ... was the time I

International Forum 53 (2015): 31-42; S. Vyas, J. Mbwambo and L. Heise, "Women's Paid Work and Intimate Partner Violence: Insights from Tanzania," Feminist Economics 21(2015): 35-58) and South African (Floretta Boonzaier, "Women Abuse: A Critical Review," in Social Psychology: Identities and Relationships, eds. Kopano Ratele \& Norman Duncan (Cape Town: UCT Press, 2003); B. Dekel and M. Andipatin, "Abused women's understandings of intimate partner violence and the link to intimate femicide," Forum Qualitative Sozialforschung 17 (2016): 1-30; K.M. Jack, "Lived experiences of women staying in physically abusive relationships," Thesis, University of South Africa (2014); S. Matthews et al. ("Every six hours a woman is killed by her intimate partner: A National Study of Female Homicide in South Africa," South African Medical Research Council (2004); A. Marais, "A narrative analysis of young people's talk of intimate partner violence," Thesis, University of Cape Town (2009) empirical studies have examined the structural and cultural factors influencing women's decisions to stay in violent relationships. Women's reasons for staying seem to include sociocultural norms of submission to men's authority; economic security and dependence; perceived risk to children; fear of reprisal by society; fear of further abuse; and the normalization of abuse by the society (B. Dekel and M. Andipatin, "Abused women's understandings of intimate partner violence and the link to intimate femicide," Forum Qualitative Sozialforschung 17 (2016): 1-30; K.M. Jack, "Lived experiences of women staying in physically abusive relationships," Thesis, University of South Africa (2014); A. Marais, "A narrative analysis of young people's talk of intimate partner violence," Thesis, University of Cape Town (2009); R. Tshifhumulo and P. Mudhovozi, "Behind closed doors: listening to the voices of women enduring battering," Gender \& Behaviour 11 (2013): 5080-5088).

10 Boonzaier, "Women Abuse: A Critical Review"; Nancy McWilliams, Psychoanalytic Diagnosis: Understanding Personality Structure in the Clinical Process, 2nd ed. (New York: The Guilford Press, 2011); George H. Young and Samuel Gerson, "New Psychoanalytic Perspectives on Masochism and Spouse Abuse.," Psychotherapy: Theory, Research, Practice, Training 28, no. 1 (1991): 30-38.

${ }^{11}$ Anna Motz, Toxic Couples: The Psychology of Domestic Violence (New York: Routledge, 2014), 38.

12 Motz. 
now started going to school ... was Sub A or B that I started noticing. We always took a piss next to the road for example, and there I thought why can I then stand and pee? And the little girl children must sit and pee. Then I now asked that question to my nephew who walked with me. Then I asked him, and he said it's a girl child that one, we are boys. Then I asked him, why does a boy stand and pee then, and a girl sit? Then he said girls can't stand.'

'So that's when I discovered I'm a man.'

'So there I started to understand, my manhood... See, it was like this for me, with the peeing, I pee faster than a girl now... the efforts she must put in, I can sommer stand just here and pee, and so it was for me. Life is better for a man.'

'Men,' he says, 'have more freedom. See, in general, a person is then so... I can take off my clothes when I'm warm and walk around with a bare chest when I'm warm. If she is warm, a woman can't take off her clothes and without a top. Or now, how can I now say... For me it's better to be a man than to be a woman. A woman, I think, has the hardest life, harder than a man.'

He continues, 'Men have easier lives than women. A man always has the easiest life, than a woman. Now see... for a woman it is difficult. See the first thing that a person thinks, if you now see a woman like today, is she, hmmm, today now already washed and dressed and, and tomorrow she now wears that which she put on today, again. The day after tomorrow she wears that again, then you start, hmmm, thinking badly of her. But a man can walk with clothes two to three days. See what I mean? Those people don't get those wrong ideas of the man in them that same time. But a vroumens, you always think badly of her. Look, the woman must always be on her neatness, like I now just talked about. The man sits outside chatting with other men. Here inside the woman must look for food for that man who is standing outside chatting so that he can eat just now. She can't chat all the time. She must manage the house. She must manage the children. She must manage everybody. Just now she must be at her job. Children must go to school ...'

In Delize's narratives about herself we see someone who consciously and unconsciously live according to powerful societal scripts like those described by her husband, but also someone who has internalized her abusive relationships by experiencing herself as dependent, powerless and shameful. According to Motz:

[Those] who were abused in early life and carry a sense of shame in relation to this, will find this shame reactivated in their violent adult relationships, and this makes it a familiar pain that, in a perverse way, confirms their fears about themselves: they are confirmed as worthless, deserving of pain. ${ }^{13}$

Delize feels that there is no other option but to be submissive and subservient, selfless and suffering. Her responsibility is to stay. As a poor coloured woman living in post-apartheid South Africa, leaving seems impossible.

However, there also is another subtle emotional thread that runs through her narrative. There is anger and indignation, a moral outrage, an insistence on justice, and also hope. She is not simply resigned to accept the injustice of the abuse, she endures the abuse and can complain about it, hoping that things will change or that she will be saved. ${ }^{14}$ Mostly, however, she feels guilty about her outrage. ${ }^{15}$

\section{Motz, 18.}

${ }^{14}$ McWilliams, Psychoanalytic Diagnosis: Understanding Personality Structure in the Clinical Process.

15 James Gilligan (2003) defines guilt as follows:

Guilt can be thought of as a defence against active aggressive wishes... When people who have developed a capacity for guilt feelings find themselves hating another person and experiencing wishes and impulses to injure them, those feelings and wishes stimulate feelings of guilt. The guilt feelings inhibit them from expressing or acting out those wishes, and motivate them to introject the anger instead, directing it against themselves, as a result of which they experience a need for punishment, which may 
Delize's story of staying is one that I am familiar with. As a psychotherapist I hear versions of it on a daily basis, in the valley, but also in my private practice.

Take for instance stay-at-home mother Cara Malan, who I also see in the afternoon of the arum lilies. As always, she arrives a few minutes late for her session, the tires of her huge white four by four screeching when she stops on the sidewalk outside my office. She is anxious, a bit breathless - with lists of things that she has to do before her husband, Johan, a distinguished professor at the local distinguished university, arrives home for his lunch and his daily afternoon nap. The to do list is impossible as always (getting the swimming pool pump fixed, having his favourite coffee roasted at the Deluxe coffee shop in a part of town where there is no parking, picking up his golf club from the sports shop, making sure that his 10 -year old whiskey is in stock, booking the ticket for his upcoming hunting trip, walking the dog, renewing his gym membership, proofreading his latest conference paper and of course keeping the three children (a toddler and two primary school kids) and their stuff out of his way.

Johan has not beaten Cara (yet), but burnt toast will make him shout and swear, her car left in the driveway between errands will make him pound on his car horn, an open door or drawer is grounds for a kid getting "'n goeie pak slae (a good hiding)" and not complimenting him on the paper that she has proofread results in a week-long sulk. Should one of the kids crumple a paper on the back-seat of the car, he will accelerate and drive too fast, scaring the whole family, thus taking revenge for the unforgivable onslaught on his tinnitus. Johan checks the wetness of Cara's vagina after they have male visitors, so as to make sure that other men do not excite her. Cleaning his car, she has found a condom under the seat. They never use condoms in their infrequent, functional, faceless and dry sexual encounters.

Cara writes to me about her shortcomings, sarcastically. 'I know I'm not perfect, Johan has thoroughly informed me of how far and on how many levels of my humanness I fall short. I probably should have tried harder.'

Cara has not (yet) thrown boiling water at Johan, but deliberately overspends on everything that Johan does not approve of, frequently bumps her expensive car, collects parking tickets by the dozen and secretly downloads and plays computer games for hours on end. She has (once), when he (once again) said to her that she is like a child without any sense of responsibility, told him to go fuck himself. That he then threw his precious glass of whiskey against the wall, went to bed without speaking to her and did not allow her to go to church with him for a month; which felt like some kind of victory.

Both Delize and Cara insist on staying on as the caretakers of their husbands and families. ${ }^{16}$ They stay because they have learned that women are defined by relationships and that it is their responsibility to care and serve in relationships in order to maintain them.

manifest itself in masochistic or even suicidal behaviour. The fear that underlies guilt feelings is the fear that one will kill a person whom one not only hates but also loves (the capacity to love others being a precondition for the capacity to feel guilty). Related to this is the fear that one will be punished by one's own conscience, or superego, because of having had such a guilty wish.

${ }^{16}$ Successive waves of feminism have engaged with women's "choice" to stay in abusive relationships. This phenomenon, called "adaptive preferences" or "deformed desires", has been described as women's unconscious responses to oppression - a "troubling, dangerous, seemingly intractable, phenomenon." See: M.B. Walsh, "Feminism, Adaptive Preferences, and Social Contract Theory," Hypatia 30(4) (2015): 834. Prominent feminist philosophers such as Catherine MacKinnon and Martha Nussbaum have insisted that feminism needs a paradigm that both recognizes the power of such choices and explains how oppression permeates the behaviour and consciousness of women, thus implicating the victims of patriarchy in their own oppression (M B Walsh, "Feminism, Adaptive Preferences, and Social Contract Theory," Hypatia 30, no. 4 (2015): 829-45.). Nussbaum specifically highlights the fact that in considering why women stay in abusive relationships, attention should be paid to the reality of asymmetrical power 
However, although women like Delize and Cara seem trapped, they are not totally without power. Women like Delize and Cara may not have overt power, are often acutely aware of the vulnerability and dependence of their violent partners. ${ }^{17}$ Sometimes they do not leave because, consciously or unconsciously they understand that the violence of their partners is a male way of expressing need and fear. If this is understood, it seems possible to forgive and to stay - rather than to further humilate a man who already feels ashamed. "Shame", Anna Motz says, "is a powerful force in maintaining violent relationships." 18

relationships, relationships of mutual dependence, or socially constructed preferences (Martha Nussbaum, "Women's Bodies: Violence, Security, Capabilities," Journal of Human Development 6, no. 2 (2005): 167-83.). More recently feminist scholars (E. Sperry, "Dupes of patriarchy: Feminist strong substantive Autonomy's epistemological weaknesses," Hypatia 28 (2013): 887-904; P. van Schalkwyk, S. Boonzaier and F. Gobodo-Madikizela, "Selves' in contradiction: Power and powerlessness in South African shelter residents' narratives of leaving abusive heterosexual relationships," Feminism \& Psychology 24 (2014): 314-331) see for instance have emphasized the importance for feminism to be "sensitive to empirical investigation into the actual choice-making of oppressed persons in their sociotemporal context". If this is not done, there is the risk of "recapitulating women's oppression by unfairly regarding such women as dupes of patriarchy." See: E. Sperry, "Dupes of patriarchy: Feminist strong substantive Autonomy's epistemological weaknesses," Hypatia 28(4) (2013): 887-904, doi: 10.1111/hypa.12007. To the extent that there is a choice to stay in abusive relationships, the preference is always socially constructed, as dominant discourses determine not only what a good woman is, but also that a woman is determined by relationship (Martha Nussbaum, "Women's Bodies: Violence, Security, Capabilities," Journal of Human Development 6, no. 2 (2005): 167-83). When thinking about women who stay, individual women and their "choices" should not be pathologized. Rather, it is the discourses that should be critiqued and subverted. In the words of Spivak; "But the real force of the struggle comes from the actual players' contemplating the possibility that to organize against homeworking (or trafficking/rape/domestic violence?) is not to stop being a good woman, a responsible woman, a real woman (therefore with husband and home), that there are more ways than one of being a good woman (Gayatri Chakravorty Spivak, "Cultural talks in the hot peace: Revisiting the 'global village'," in Cosmopolitics: Thinking and feeling beyond the nation, eds. Pheng Cheah \& Bruce Robbins (Minneapolis: University of Minnesota Press, 1998), 342-343"

17 Poststructuralist feminists, working in the field of intimate partner violence have emphasized how women in abusive relationships fluctuate between positions of power and powerlessness in relation to their abusers. See M. Hydén ("The World of the Fearful: Battered Women's Narratives of Leaving Abusive Husbands," Feminism \& Psychology 9 (1999): 449-469); V. Enander ("Jekyll and Hyde or "Who is this guy?' - Battered women's interpretations of their abusers as a mirror of opposite discourses," Women's Studies International Forum 33 (2010): 81-90; "Leaving Jekyll and Hyde: Emotion work in the context of intimate partner violence," Feminim \& Psychology 21 (2011): 29-48) and P. van Schalkwyk, S. Boonzaier and F. Gobodo-Madikizela "'“Selves' in contradiction: Power and powerlessness in South African shelter residents' narratives of leaving abusive heterosexual relationships," Feminism \& Psychology 24 (2014): 314-331).

18 Anna Motz ("Toxic Couples: The Psychology of Domestic Violence" (New York: Routledge, 2014: 38) explains: ...the awareness that there are fears and terrors that can drive people to control others so wholly, is another factor that can stop women from leaving violent men... Like good therapists, they understand that underneath the aggression there is so often fear, isolation and emptiness, and that violence is the way in which such people communicate this need without losing face. There can be the feeling that to transcend one's own pain and humiliation, to forgive and understand the violent partner, is the best way to act. When this self-sacrificing attitude is socially sanctioned and the partner also offers affection, attention and even care, at some times, it can be hard, if not impossible, for a battered partner to find a different voice, and to allow their own sense of outrage to surface... 


\section{Shamed and dependence}

Surprisingly, Piet Plesier, Delize's husband, when we do meet him, does not fit our stereotype of a violent abusive husband at all. Somehow the seemingly scary men never do.

Piet is slightly built, has a limp hand and smiles all the time, incessantly. His eyes are watery although he never cries. Piet is seen by a thirty-year-old male student and tells us a different story about his relationship with Delize. According to him, the disagreements and arguments in the household are few and they are typically solved amicably, behind closed doors. He describes the ideal husband. 'The two of them like each other. He's not the man who'll actually lift his hands against his wife. They love one another, and the children also love them. There's no arguing among them.'

He talks about the joys of fatherhood. 'There are things that make me feel good. Because you now the. How can I now say, always when you come into the house, they respect you. It makes you feel you are here. The highest in the house. The main person in the house. Look, you get that feeling. It's a good feeling. They're not rude to me or so. Always nice talking, good company.'

Piet is also quite clear about what a bad husband is. 'Meneer, there's sommer many around. Always arguing, always wanting to fight, always saying bad words, such horrible bad words, and in public. Fighting in public.'

He lives his one hand in a threatening way and says loudly, 'I'll give you a belse klap hellwwa smack now, or I'll kick you.'

He drops his hand, his voice softer, but he seems upset. 'Like that, in public. So that sort of life they now have. The sommer chase the kids around. So that poor little kid, you mos already make him scared of you. Wild for you. Now in that time that you chase him around like that, you already teach him how he should chase people, fight and so.'

Piet links the feeling of being respected to being a loving husband and portrays himself as such. The therapist, frustrated, writes in his journal that he thinks that Piet just told him what he thought would be the right thing to say. 'Also,' he says, 'Piet clearly did not think that he could have refused to come for a session and tellingly said at the beginning of the interview: "Meneer can maar ask questions, I will reply..."

Meneer is ten years Piet's junior.

This kind of obedience or acquiescence is something Piet learned as a child. He loved his parents, he says, he did what they told him to do. 'There's not actually something for me against my parents, in the house. I always did as they said.' He describes a childhood dominated by rules, discipline and punishment with a clear ground rule that children should not be seen nor heard. 'That time, in the olden days, it was like that ... when I come from school in the afternoons... when we finished eating, take school clothes off, school work, if you got homework from school, finish. And first finish your afternoon jobs, then you have to ask, may you go and play now. Now you maybe have an evening job too that you have to finish before dark. Collect wood, and bring wood into the house, and maybe fetch water or so. Now maybe you played out late there with the chommies, and you forgot that job. My parents were like that, if you didn't do it, the sjambok always hung there against the wall. I got many hidings.'

He feels it was good that his parents were strict. 'So I began to understand my life from there, understand, understand how life goes. Look, if Meneer and I made an appointment for today now. Meneer came now, and I have, I'm not here. Then Meneer would have felt bad, and afterwards I would have remembered, I mos had another appointment. It will now have stayed in my thoughts, it will now bug and bug and bug me.' 
In the interview there is little sign of the violent husband, the enraged father, the man who spent almost three years in jail for messteek (stabbing someone with a knife) and another two years in hospital for stab wounds that he obtained in a subsequent fight.

On the depression questionnaire, administered at the end of the session, Piet scores "severely depressed", despite him saying to the interviewer at the beginning of the session: "Today I feel happy Meneer, I'm a person who never has many worries. I, like my parents taught me, must accept all people, as I accept myself.'

By the end of the session Piet appears to be exhausted and reluctantly admits that he sometimes drinks one beer to many. 'I can't actually, my wife does not really want me to drink. Now I go drinking and I come back, then she always talks to me in such a kind of rowwe manier (rough manner). And those are things that I also don't like. It is not lek.ker. If she talks such things with me. I like it if we always talk to each other properly.'

The consequences of his drinking, he says, are not good. He lowers his head and looks down. 'I think wrong things, I do wrong things and so. I scold and swear. Wrong things. Always the wrong things. And if you then become sober, then you feel bad about it. Ashamed, I am ashamed, ashamed that's how I feel.'

His replies now are brief, his sentences short. The most prominent emotion of the wifebeater seems to be shame.

I think about Piet's words about violent fathers: 'Now in that time that you chase him (the child) around like that, you already teach him, how he should chase people, fight and so,' and I wonder where Piet learned to fight. Earlier on in the interview he talked about the worst hiding he ever received as a child. 'One morning I got a big hiding from my father. I did, before I went to school nou, I peed in the kooi (vernacular for 'bed'). Peed in the kooi while I was sleeping. And that my father never liked. I was like eight, daar rond (approximately). My father hit me all the way to the school, the school was not far from us. All the way to the school. And in front of the teacher he also hit me. Lyfhoue, en stere-houe en bene-houe, so (blows to my my body, my bum, my legs) ... Thick blows so with the sjambok, those. It was actually for me, that morning the worse hiding that I got from my parents. It was two weeks, two weeks before I could sit. My parents mos didn't know doctors. They made their own stuff to heal sores, and so. Stukkende plekke (injuries caused by blows in which the skin is cut or broken) everywhere. On my bum. All over my body. At night when I sleep, I lie now on my tummy, because the other side with stukkende plekke hurts.

Piet's painful story about a hiding in which his bed wetting ${ }^{19}$ was punished in a very public way is again a story of shame. ${ }^{20}$

In the valley many violent interactions start with the sentence 'Moenie my vir " $n$ poes vat nie" (Don't take me for a cunt)', meaning don't underestimate me, don't disrespect me. American psychiatrist James Gilligan, who worked with violent criminals for decades is convinced that the most powerful way to provoke anyone into committing violence is by shaming him. The

19 Gilligan ("Shame, guilt, and violence," Social Research: An International Quarterly 70 (2003): 1149-1180) argues that one only has the capacity to feel guilty if one is aware of your own strengths and skills. He says: It is only those who continue to see themselves as weak and incompetent who do not develop the capacity for guilt feelings. These are not just words or theories, nor do the examples given apply only to children. I was amazed to discover how many violent criminals still wet the bed, for example, over which their feelings of shame are almost unlimited.

20 There are many synonyms for being shamed: being slighted, insulted, disrespected, dishonoured, disgraced, disdained, demeaned, slandered, treated with contempt, ridiculed, teased, taunted, mocked, rejected, defeated, subjected to indignity or ignominy; feelings of inferiority, inadequacy, incompetence; feelings of being weak, ugly, ignorant, or poor; of being a failure, "losing face," and being treated as if you were insignificant, unimportant, or worthless, or any of the numerous other forms of what psychoanalysts call "narcissistic injuries". 
most powerful way to shame anyone, he says, is by means of violence. Think Cain and Abel, the Trojan War, the Second World War and the Weimar. Violent interactions always start with someone or something being shamed. Also, Gilligan says, people resort to violence when they feel that they can wipe out shame only by shaming those who they feel have shamed them. ${ }^{21}$

This vicious cycle is clear in Piet's story of rough times. 'Daai tydjie (that short little time) that I now started getting rough, at that age that I was not going to be told by anyone. Lots of arguments. Ligte bakleitjie. (Light little fights). I used a knife once, in that time. Then I stab one chappie, eight gashes with the knife. And they charged me by the law. He survived, he's still alive. Charged by the law, and the law punished me. I went to jail. That is now because of the gashes. Got two years and six months.'

Jail, however, was not the end of his punishment. 'After that when I now came out of the jail, then I went to my sister and them's house that my parents left for us. Now one day, it was so half cold in the winter then. Now we stand outside in the yard round the fire that we now made, now we stand around the fire like that. Now that one, that I now stabebed, the one with the eight gashes, his nephew stabbed me, a betrek-hou (a blow given by taking hold of someone). He pulls me toward him, and he stabs me here in the head.' He touches his temple. 'So that the knife's blade comes out here.' He indicates the back of his head. 'Through my head. I just saw him stab, he lifts his hand and he comes with the knife. This is the last thing I knew. When I woke up, then I was lying in the Cape in Tygerberg Hospital. I lay in the Cape in Tygerberg Hospital for a year and six months.'

The person who has been shamed can be thought of as having been killed psychologically. ${ }^{22}$ The the self has died. People are psychologically killed (their humanity is taken away) if they are being treated with contempt or disrespect, as though they are unimportant or insignificant. Gilligan says:

...one after another of the most violent men I have worked with over the years have described to me how they had been humiliated repeatedly throughout their childhoods, verbally, emotionally, and psychologically (taunted, teased, ridiculed, rejected, insulted). They had also been physically humiliated by means of violent physical abuse, sexual abuse, and life-threatening degrees of neglect (such as being starved by their parents, or simply and totally abandoned, as in coming home to find that their parents had absconded from the family's apartment, leaving them behind). ${ }^{23}$

Shame, Gilligan says, can be understood as a defense against both an unbearable longing and a ghastly fear. The need is to be taken care of and loved.

... shame can be [understood as a defense] against wishes to be loved and taken care of by others... When people... find themselves wanting to be loved and taken care of by others, they experience an upsurge of shame, which typically motivates them to move in the opposite direction by becoming active and aggressive, independent and ambitious. If they do not perceive themselves as having nonviolent means for becoming independent and being able to take care of

\footnotetext{
21 J Gilligan, "Shame, Guilt, and Violence," Social Research: An International Quarterly 70 (2003): 1149-80.

22 The word mortification, which means overwhelming humiliation, comes from Latin roots that mean

"to make dead" (mortis, dead, and facere, to make).

23 Gilligan, "Shame, Guilt, and Violence," 1153.
} 
themselves (such as skills, education, and employment), the activity and aggressiveness stimulated by shame can manifest itself in violent, sadistic, even homicidal behavior. ${ }^{24}$

The fear is of being abandoned, rejected or ignored.

The fear that underlies and stimulates feelings of shame is the fear that one will be abandoned, rejected, or ignored and will therefore die because one is so weak, helpless, dependent, unskilled, and incompetent that one cannot take care of oneself, because of which one is also so inferior, unloveable, and unworthy of love that one probably will be abandoned. This is implied, and entailed, by the fact that the self-image that stimulates shame is the image of oneself as a helpless, dependent infant who would die of starvation if abandoned by a parentfigure. ${ }^{25}$

Piet, the ashamed wife-beater, despite the shameful hidings has also loved and had opportunity for love. He remembers his father with tenderness, certainly someone that he liked to be seen with and spoiled by: 'And we children loved to go to my dad's car, or to the bakkie. We were there. So I and we grew to love my dad and got used to. Loved them now, as they give us the opportunity now, so we also got used to the opportunity now, and do as they want it ... I always loved walking with him to church, Sundays ... Chat, and I always get sweets from my dad, or my dad buys me a sucker, or so. You now walk past the shop. Shop that he now walks past. So I came to love ...'

Piet says about his mother: 'My mom was a good mom for us. Kleertijes (diminutive for clothes) always clean, and kossies (diminutive for food) was always on time for us ... I felt very close to my parents. The day that my mom died ... Meneer, that day we cried.'

A man like Piet thrives when he gets respect and recognition ${ }^{26}$, the opposite of disrespect and contempt. In psychology we talk about the curative power of being seen, being attended to. ${ }^{27}$ The danger, with men like Piet is that instead of being admired and respected by the women in their lives, they will be detested and despised, also leading to them being disrespected by their children.

However, to explain the intricacy of the shame it is crucial to embed individual biography in the larger matrix of culture, history and political economy. ${ }^{28}$

A violent person's venture into psychotherapy may be one attempt to be seen, to be recognized and respected. Punishment may take guilt away, but may, simultaneously, increase feelings of shame. Gilligan says: "That is the basic psychological reason why punishment- that

\footnotetext{
${ }^{24}$ Gilligan, 1167-68.

${ }^{25}$ Gilligan, "Shame, Guilt, and Violence.": 1168-1169.

${ }_{26}$ Gilligan, 1157.

In Gilligan's words:

Recognition is both etymologically and psychologically related to re-spect; the former derives from Latin words meaning to "know again," to "re-know," so to speak, and the latter from words meaning to "see again," to take a second look. Both words imply that the person is important enough to be worthy of a second look, and well-known enough, renowned enough. To be worthy of being re-known, ac-knowledged, re-cognized.

27 When love is considered, recognition and respect are central. In Nicole Krauss' (2005) novel, History of Love, the main character, an elderly man, poignantly talks about the very human need for recognition: I try to make a point of being seen. Sometimes when I'm out, I'll buy a juice even though I'm not thirsty. If the store is crowded I'll even go so far as dropping my change all over the floor, the nickels and dimes skidding in every direction. [...] All I want is not to die on a day when I went unseen.

${ }^{28}$ Paul Farmer, Pathologies of Power. Health, Human Rights and the New War on the Poor. (Berkeley: University of California Press, 2005), 41.
} 
is, revenge- far from deterring or preventing violence, is the most powerful stimulant or cause of violence that we have yet discovered". ${ }^{29}$

If a young man who exhibits a potential for violence should be further shamed on a continuous basis and the shame and humiliations become so intense that it is overwhelming, he may become unable to see the other options for self-respect and resort to the violence of gang life as a way to get self-respect. The danger of this happening in a context where he is part of demographic group that, in post-apartheid South Africa, is still subjected to systematic shaming, is great. Race is still a huge issue. Uneven development has also ensured that young people may even have fewer opportunities than their parents. Neo-liberalism will make their escape from the cycle of shame and violence their own individual responsibility. A dominant patriarchal culture, where violence is often seen as a way of maintaining one's masculinity or sense of masculine sexual identity, will certainly also serve to make it difficult for young men to escape the cycle. In South Africa in general, but in the valley in particular; violence has become a way of communicating and often is honoured, with nonviolence being shamed.

Young men's potential problem with shame and violence is, therefore, not simply an individual problem caused by abandoning parents and an angry wife. It has to do with the fact that in contemporary society there is, as Gilligan will say, "a general sense that very little respect is to be had." 30 This is particularly true when people are poor and do not have jobs that pay a living wage and where racial discrimination is still determining who shall be respected and who not. It is as if "everyone competes to get what affirmation he can from what is available." 31 People are needy, angry and aggressive. In such an unequal society, Gilligan says, "for the severely alienated and desperate a gun can become like a bank card- 'an equalizer' in the contest for respect, and for the material status symbols that are among the main bases of respect." 32

The point thus is to try to take account of the inner world and the outer world simultaneously. When psychoanalyst Donald Winnicott, famous for his statement that there no such thing as an infant, there is only an infant and his mother, discusses his concept of holding, he says: "One can discern a series - the mother's body, the mother's arms, the parental relationship, the home, the family including cousins and near relations, the school, the locality with its police stations, the country with its laws". ${ }^{33}$ What shapes a persobut all caretakers and caring institutions: the larger family, the community, the schools, the hospitals, the psychologist, the police, the government and even larger societal institutions and processes.

In the words of Willem Anker in the novel Buys: "Elke man met 'n piel en ' $n$ spies en 'n roer in sy band het ' $n$ ma. (Every son with a gun or a spear or a prick in his hand has a mother.) '34

\footnotetext{
${ }^{29}$ Gilligan, "Shame, Guilt, and Violence," 1164.

${ }^{30}$ Elijah Anderson, Code of the Street: Decency, Violence, and the Moral Life of the Inner City (New York: Norton, 1999), 75.

31 Anderson, Code of the Street: Decency, Violence, and the Moral Life of the Inner City.

32 Gilligan, "Shame, Guilt, and Violence," 1161; Anderson, Code of the Street: Decency, Violence, and the Moral Life of the Inner City, 119.

${ }^{33}$ D. W. (Donald Woods) Winnicott et al., Deprivation and Delinquency (London: Tavistock Publications, 1984), 125 , https://books.google.co.za/books/about/Deprivation_and_Delinquency.html?id=SBUvQAAACAA J\&redir_esc $=$ y.

34 W. Anker, Buys: 'n Grensroman (South Africa: NB Publishers, 2014).
} 


\section{Care and rage}

Woman of stone, heart of iron,

Disconsolate woman, ready to kill.

The seed of your hands with the hand that tilled. ${ }^{35}$

How did it happen that I, who, as a researcher and clinician, wanted to focus on motherhood and caring, end up writing mostly about vulnerability, shame and violence? I should not have been surprised. Depictions of the violent side of caring, specifically of mothering, are old and everywhere.

While writing the book. I do a paper on murderous mothers in Prague. I visit the Kafka museum. The first exhibit is a letter Frans Kafka wrote about the complex relationship he had both with his mother and his mother city. He says, "Prague never lets you go... this dear little mother has sharp claws." I read Zadie Smith's, The authograph man, she writes about a Jewish mother as "a violent tea cozy". ${ }^{36}$ I tell my daughter the story of Snow White. It is the stepmother that poisons the sensual Snow White by combing her hair and dressing her up in lace, finally killing her by feeding her a red apple.

Stonewoman. Ironheart.

This is how Euripedes, in the year 341 before Christ describes the epic and maybe most notorious violent mother of all times, Medea. In the play Medea kills her two sons when she hears about the infidelity of her husband, Jason. Euripedes, who certainly had empathy with his notorious heroine, describes her emotional state as "disconsolate", she was hopelessly unhappy and unable to be comforted. Euripedes also provides a reason for her distress and her act of murder. He lets her say: "Of all creatures that can feel and think, we women are the worst treated things alive." 37

One of the biggest challenge of post-Apartheid South Africa is to understand why, almost systematically, the institutions that are supposed to be caring have become violent and cruel. We have to understand why this is so. ${ }^{38}$

One such institution is the institution of motherhood. ${ }^{39}$

${ }^{35}$ Euripides, Euripides: Medea, ed. Donald. J. Mastronard (Camrbidge: Cambridge University Press, 2002).

${ }^{36}$ Zadie Smith, The Autograph Man : A Novel (London: Hamish Hamilton, 2003), 138.

${ }^{37}$ Euripides, Euripides: Medea.

38 One day, in the year 2000, Pumla Lolwana walks into a train on the Cape Flats with one child in her arms, two holding on to her hand. Athol Fugard writes a play about this incident called The Train Driver, and says:

I think all of my writing life led up to the writing of 'The Train Driver' because it deals with my own inherited blindness and guilt and all of what being a white South African in South Africa during those apartheid years means (Reed Johnson, "Athol Fugard Finds Truth and Reconciliation in "The Train Driver,"' Los Angeles Times, 2010, rticles.latimes.com/2010/oct/15/entertainment/la-et-athol-fugard20101015.).

${ }^{39}$ In the early days of feminism Adrienne Rich (1986), a feminist poet, writes about "the invisible violence of the institution of motherhood". In her book Mother Instinct, a meticulous historical, biological and psychological investigation of the idealization of motherhood and the myth of mother instinct, the anthropologist Sarah Blaffer Hrdy (Mother nature: a history of mothers, infants, and natural selection (New York: Pantheon Books, 1992: 25) writes: "From the 1980s onward, however, there was increasing awareness that infant abuse, neglect, abandonment and infanticide were far more widespread than even those of us who studied such phenomena had realized. I already knew that abandonment - both in humans and other animals - stretched far back in evolutionary time. I just had not realized the magnitude of what was going on." She cites author George Eliot (1955: 272-273) as writing: "Mother Nature - who by the bye is an old lady with some bad habits..." 
There is an Afrikaans lullaby that many Afrikaans children grow up with. I remember my mother singing it to me at bedtime. The song rather ominously depicts the dynamic life cycle of a man's ambivalent relationship with his ever-present mother. The mother sweetly lulls the baby to sleep on her lap, protects him against looming dangers, but she also abuses, abandons and kills. Even when he is a grown man, the mother is intrusive and she keeps the man small, a baby forever, "tot hul dood (until they die)".

Siembamba, mamma's little lamb,

Siembamba, mamma's little lamb,

Wring his neck, dump him in the ditch,

Step on his head, then he's dead.

Siembamba, I'm a baby now,

Siembamba, I'm a baby now

Keep me safe in my need,

Lull me gently in your lap.

Siembamba I'm mamma's little boy,

Siembamba I'm mamma's little boy.

But watch me well I'm growing up,

Won't take shit from other chaps.

Siembamba, I'm mamma's young man now,

Siembamba, I'm mamma's young man now,

You can let me go from your warm lap now;

Ready to kill the other fellows now.

Siembamba, I'm a married man now

Siembamba, I'm a married man now,

But mamma thinks I'm mamma's boy still,

Won't believe I'm grownup now.

Siembamba, all are mamma's boys

Siembamba, all are mamma's boys -

All the men so grown-up, so they say -

All are babies till they die. ${ }^{40}$

40 CJ Langenhoven, "Siembaba," accessed May 22, 2018, http://tortel.net/ lochner/blerkas/woorde/190.txt..

Siembamba, mother's little child,

Siembamba, mother's little child,

- ring his neck, throw him in the ditch

step on his head and he is dead.

Siembamba, I am a baby,

Siembamba, I am a baby,

- keep me safe when I'm distressed,

lull me sweetly at your breast.

Siembamba, I am a little boy,

Siembamba, I am a little boy,

- but you'll see I'll soon be grown;

just strike uncalled-for fellows down.

Siembamba, I am a young man,

Siembamba, I am a young man,

- you can let me off your breast now;

I'll strike those fellows dead I vow.

Siembamba, I am married now,

Siembamba, I am married now, 
The line between nurturing and poisoning, giving life and killing, is indeed a fine one.

she was my mom

and she taught me

how not to love

myself.

Yet, she was also:

the woman that

kept her sick leave

for when someone

else in the house falls ill. ${ }^{41}$

Although many women hurt others, such violence is often ignored. ${ }^{42}$ As with women's anger and hostility, violence among women is still not expected or accepted, as

but she thinks I'm still at her breast,

doesn't believe I'm out of her nest.

Siembamba, all are babies,

Siembamba, all are babies,

- all the men are rather old -

all are babies till they're cold.

Lullaby in Afrikaans:

Siembamba, mamma se kindjie,

siembamba mamma se kindjie,

draai sy nek om, gooi bom in die sloot,

trap op sy kop dan is by dood.

Siembamba, ek is ' $n$ baba,

Siembamba, ek is ' $\mathrm{baba}$

--pas my veilig op in die nood,

sus my liefies op die skoot.

Siembamba, ek is ' $n$ seuntije,

Siembamba, ek is ' $n$ seuntiie

maar jy sal sien ek, is net nou groot;

slaan maar orige kêrels dood.

Siembamba, ek is 'n jonkman,

Siembamba, ek is 'n junkman

--tel my nou maar af van die skoot;

ek slaan self die kêrels dood.

Siembamba, ek is getroud nou,

Siembamba, ek is getroud nou

--maar sy dink ek is nog op die skoot,

wil nie glo nie ek is groot.

Siembamba, almal babas.

Siembamba, almal babas

--al die mans is danig groot-

Almal baba's tot bul dood.

${ }^{41}$ Ronelda Kamfer.

42 DM Currier, "The Psychology of Female Violence: Crimes against the Body.," Feminism \& Psychology 14, no. 4 (2004): 601-3.

I myself am more than ever aware of the complexity of violence and the shameful secrets of violence we all carry within ourselves and our societies and how we desperately defend against this darkness by dichotomous thinking, simplification, vilification, idealization and fierce denial. As a feminist, it was very tempting, not to write about violent women - both for political but also deeply personal reasons. 
it is not in line with traditional gendered beliefs. Violent mothers in particular present a challenge. ${ }^{43}$

While many of the women we encounter in the valley present like Delize, ${ }^{44}$ that is with symptoms typically associated with a diagnosis of depression, ${ }^{45}$ for many so-called depressed women feelings of hostility and anger were actually more prominent. ${ }^{46}$ However, anger and hostility are not acknowledged as a symptom of depression in formal diagnostic systems. ${ }^{47}$

Constructions of femininity dictate that "good" women are calm, in control and selfsacrificing in relationships and that they engage in self-silencing feelings or behaviours in order

${ }^{43}$ B Naylor, "The 'Bad Mother' in Media and Legal Texts," Journal of Social Semantics 11, no. 2 (2001): 155-76..

${ }^{44}$ Delize seems to suffer from introjective depression. The introjective depressed person tends to take responsibility for her own sadness and feels that the source of unhappiness lies within herself. She feels that if she can become a better person and improve, life will be better. She feels bad about herself, but powerful in that badness. The bad in the world and in other people is introjected, thus the world can be kept good and other people are idealized. By turning against herself, she has a sense of power and her anxiety is less. She also denies or represses her own anger and hostility.

45 Typical symptoms of depression include depressed mood, low energy, low appetite, low libido, inability to concentrate, hopelessness, listlessness, sleep disturbance (American Psychiatric Association, Diagnostic and Statistical Manual of Mental Disorders: DSM-5 (Washington, DC: American Psychiatric Association, 2013).).

${ }^{46}$ Lou Marié Kruger and Marleen Lourens, "Motherhood and the 'Madness of Hunger': '...Want Almal Vra Vir My Vir 'n Stukkie Brood' ('...Because Everyone Asks Me for a Little Piece of Bread')," Culture, Medicine and Psychiatry 40, no. 1 (2016): 124-43.

${ }^{47}$ Researchers and clinicians acknowledge a relationship between anger and depression (Newman et al., 2006), but anger is not recognized as a symptom of adult depression in most formal diagnostic systems. Epidemiological studies investigating a link between anger and depression have found gender to be a key variable (TD Hill and BL Needham, "Rethinking Gender and Mental Health: A Critical Analysis of Three Propositions," Journal of Social Science and Medicine 92 (2013): 83-91.). It is more acceptable for a woman to be depressed than to be angry (Dana Crowley Jack (Bebind the mask: Destruction and creativity in women's aggression (Cambridge: Harvard University Press, 1999: 169)). J.L. Newman et al. ("Gender differences in the relationship of anger and depression in a clinical sample," Journal of Counseling and Development 84 (2006): 161) hypothesize: “...the seeming compatibility of depressive symptoms and the corresponding incompatibility of anger symptoms with the feminine gender role may greatly increase the likelihood that psychological distress in women is manifested in depression rather than anger, regardless of underlying aetiology". The biomedical framing of a diagnosis of depression and the subsequent obscuring of anger can serve an important (if problematic) protective role in women's constructions of self (M. Lafrance \& S. McKenzie-Mohr, "The DSM and its lure of legitimacy," Feminism \& Psychology 23 (2013): 119-140).

The only diagnosis in the DSM-5 that includes anger as a symptom is Intermittent Explosive Disorder, a diagnosis which cannot be made before age six years or after age 18. This diagnosis includes the following criteria:

-Severe recurrent temper outburst manifesting verbally, behaviorally that are grossly out of proportion in intensity or duration to the situation or provocation

-Temper outbursts are inconsistent with developmental level

- Occur on average two or three times a week

- Mood between temper outbursts is persistent irritability or anger most of the days

-Symptoms have been present for 12 months, never three months without symptoms

-Symptoms presents at least two of three settings (home, school, peers) (American Psychiatric Association, Diagnostic and Statistical Manual of Mental Disorders: DSM-5.) 
to conform to these ideals. ${ }^{48}$ "Good" women should not experience, much less express, anger. ${ }^{49}$

The idealization of the early mother-baby bond as the "most perfect, the most free from ambivalence of all human relationships" 50 has led psychologists to pay little attention to the anger of mothers. As Raphael-Leff writes, even feminist psychologists have failed to explore "painful maternal experiences of ambivalence, persecution and hatred". ${ }^{51}$

In the valley, feelings of anger and hostility manifest in different ways. Aggressive fantasies are frequent. Scolding, swearing, shouting and yelling are often reverted to. Sterretjie, a woman diagnosed with depression talks about her anger and how it manifests. 'Because I shout at my children a lot. I shout and just swear, because then I am very angry. I get hugely upset and now, then I can't get rest. Oh, I can't, I am now going to scold, on and on and on.' She claps her hands. Cathy, another woman diagnosed with depression, is as angry. 'Yes, I yell at them (children) a lot, really, I yell a lot,' she says. 'I yell at them about anything they do. If they make a small mistake, I will yell at them.'

In the valley, women often talk about how their anger leads to violence. They are mostly violent in their households, with partners and children as the targets. The violence that we hear about sounds quite extreme. However, it is quite common for South African mothers to use corporal punishment. ${ }^{52}$

48 Newman et al., "Gender Differences in the Relationship of Anger and Depression in a Clinical Sample"; DC Jack, Silencing the Self: Women and Depression (Cambridge, MA: Harvard University Press, 1991).

${ }^{49}$ Dana Crowley Jack (Behind the mask: Destruction and creativity in women's aggression (Cambridge: Harvard University Press, 1999: 169)) claims that the division between an outward self that is conforming, and an angry and resentful inner self is "the core dynamic of female depression". Depressed women are likely to internalize anger and articulate it as self-blame and self-doubt. Other feminist psychologists assert that both suppressed anger (anger-in) and anger expressed in verbal and physical aggression (anger-out) are implicated in women's depression (E. Sperberg and S. Stabb, "Depression in women as related to anger and mutuality in relationships," Psychology of Women Quarterly 22 (1998): 223-238). L. D. Blum ("Psychodynamics of postpartum depression," Psychoanalytic Psychology 24 (2007): 54) asserts that "although over-control of anger, with repression of it and/or guilty self-reproach for it, is a problem, loss of control is an opposite risk... Occasionally loss of control threatens to follow from overcontrol, as internal pressure builds up".

Anger also seems to play an important part in maternal depression. For instance, depressed mothers often experience recurring obsessional thoughts of harming an infant, even though they are horrified by those thoughts and keep them secret (L. Murray and M. Finn, "Good mothers, bad thoughts: New mothers' thoughts of intentionally harming their newborns," Feminism \& Psychology 22 (2012): 41-59; J. Barr and C. Beck, "Infanticide secrets: Qualitative study on postpartum depression," Canadian Family Physician 54 (2008): 1716-1717).

${ }^{50}$ Freud in J Raphael-Leff, "Healthy Maternal Ambivalence," Studies in the Maternal 2 (2010): 2.

51 Raphael-Leff, 3.

52 Dawes et al. (2005) found that $57 \%$ of adults with children in a national sample reported that they had smacked their children in the past year. Of the parents, $60 \%$ said that they had used a belt or another object to beat a child in the past year (33\% of the total sample). Women smacked children more frequently than men $(70 \%$, as compared to $30 \%)$. These findings suggest that females are more likely to use physical violence against children than males (A. Dawes et al., "Survey examines South Africa's attitude towards corporal punishment," Article 191 (2005): 2-4; R. Gelles, "Violence in the family: A review of research in the seventies," Journal of Marriage and the Family 42 (1980): 873-885) - perhaps not surprising given that women typically spend much more time with children than men do. Although men are generally more violent than women, women tend to aim their violence at their own bodies and those of their children (Anna Motz, The psychology of female violence: Crimes against the body (New York: Routledge, 2001). In working in low-income communities, we have frequently heard accounts of women who lash out at their children in states of agitation and rage. Anecdotal reports of mothers who kill their children 
Leila describes her anger; 'Rage within me that wants to come out. It is like a thunderstorm. Nothing and nobody should lie in front of me, nothing is right for me. And then the rage push up in me and then no one should be in my way, because then I simply am that angry bear. I would say if I have to describe my depression, I am just pissed off today. Today, today no one should mess with me.'

She continues, 'Then I ask God silently to make me calm, tranquil, because I [hate] the way when they [children] made me angry to attack them with the fists or I strangled them or threw things at them to get my way. I later on thought that is why my children are like this, because I keep on scolding.'

Why are the women so angry and aggressive?

Not surprisingly, women's reasons for being angry are typically related to relational experiences and their disappointments in relationships. Women are angry about relationships and their deficits. ${ }^{53}$ Women are distressed that their children are not living up to their expectations, not fulfilling their hopes and dreams. Most women know the feeling. Antjie Krog writes as a middle-class white mother.

and I go crazy

my children assault me with their rowdiness

selfishness

cheekiness

destructiveness

their fears complexes insecurities threats needs

beat my "image as mother" into soft steak on the wooden floor ${ }^{54}$

The mothers we speak to also often relate their anger and violence to pain and disappointments associated with not being the mothers they wanted to be.

I smell of vomit and shit and sweat

of semen and leeks

I sulk like a flour bag

I am chipped like a jug

my hands drier and older than yesterday's toast

give half-hearted slaps against the clamour ${ }^{55}$

are not infrequent (L-M. Kruger, “'Vrot kolletjies' : shame, silence and enactment in psychotherapy with impoverished clients," Psycho-analytic Psychotherapy in South Africa 20 (2012): 1-32).

${ }^{53}$ Low mutuality is associated with more anger suppression and/or less control over expression of anger. As Swartz ("Feminism and psychiatric diagnosis: Reflections of a feminist practitioner," Feminism $\&$ Psychology 23 (2013): 41-48) states, although the relational difficulties of volatile, angry and demanding women are often attributed to internal instability, women are often reacting to a disturbed and disturbing intersubjective field, which is situated in a specific context.

54 en ek word mal

die kinders rand my aan met bulle luidrugtigheid

selfsugtigheid

astrandheid

vernielsugtigheid

bulle vrese komplekse onsekerbede dreigemente node

kap my "beeld as moeder" steaksag op die plankvloer.

55 ek ruik, na kots en kake en sweet

ek is dikbek soos'n meelsak.

afgechip soos ' $n$ melkbeker

my hande ouer en droër as gisteroggend se toast

deel slae nit halfhartig teen die kabaal

gaan sit dan bierdie sondagmôre op die treetjie 
Ideal mothers and ideal children seemed to be implicit in all the anger narratives.

Twela talks about the type of person she wants to be, 'I don't want to be that person, that bad person, like swearing and whatever. And I don't want to be impatient. It isn't right to swear to express your feeling, to be impatient to express your feeling, it isn't right.' She continues, 'Yes and I don't want that angry. It's, it's frightening. I don't want that angry. And, and, and it isn't good because, ah, we can do anything wrong, you can for instance, can make somebody hurt or you can hurt yourself. I don't want that kind of angry. I want to talk with a kind voice but I don't want to shout back and ignore them or whatever, I don't want to do that.'

'And then we just argue and, I'm so scared that, that I might, that I might do the thing to my child or if I, just, ah, that feeling that I have, boe kan ek nou sê (how can I say)? That, that, that feeling what I had inside me, that, that, that bitterness and all that dark things that I had, ah, hoe kan ek nou sê (how can I say)? Ah, that I can give it to him.'

It is difficult to be a mother.

I go outside and sit on the step this Sunday morning

neither sober nor embarrassed

wondering

how and with what does one survive this? 56

We might not.

\section{Repetition and ambivalence}

The whole of our culture in the west depends on the murder of the mother,

Luce Irigaray ${ }^{57}$

I learned from you

To define myself

Through your denials

Audre Lorde ${ }^{58}$

In the valley it is not only the boys and the men who have learned the language of violence. The girls know early on that relationships and families are dangerous places. Heterosexual relationships are almost automatically equated with betrayal and violence, even by very young women.

My students in clinical training run an empowerment group with 13-year old young women or girls. The topic is "your dreams" and the pony-tailed girls are boisterous. They talk loudly, interrupting each other and underlining their words with gestures and movement. In

\footnotetext{
neither nugter nor verleё

en wonder

boe en waarmee oorleef mens dit?

56 gaan sit dan hierdie sondagmôre op die treetjie

neither nugter nor verlë

en wonder

hoe en waarmee oorleef mens dit?

${ }^{57}$ As cited in M Whitford, "Maternal Genealogy and the Symbolic," in Luce Irigaray: Philosophy in the Feminine, ed. M Whitford (London: Routledge, 1991), 75.

58 "Black Mother Woman" in Audre Lorde, From a Land Where Other People Live (Detroit: Broadside Press, 1973).
} 
the group they are asked what they see as the biggest potential problem that they will have to face in life:

'Outjie problems (boy problems),' says Sandra without hesitation. 'He... he cheats on you with someone else...he beats you. My ma says if a boy beats me like that one day, he will always beat me, and then I should leave him.'

Kaitlyn is adamant that she will fight back. 'No, my antie told me if the boytjie hits me, I should hit him back. My houe is in (My blows are in).'

Sandra is still convinced one has to leave. 'But I will still leave him even though I gave him a lekker beating.'

Mishka agrees. 'I will first hit him and then I will leave him. Then he will know he won't mess with me again.'

Sandra can see it. 'Then his eyes are swollen...'

Mishka elaborates. 'I will throw boiling water at him...'

Sandra explains how she will do it. 'I will hit him with the pan...'

The young therapist is nervous. 'Sjoe jong (Sho man), that is a lot of rage.'

Kaitlyn says, Ek sal vir hom warm knyp met' $n$ tweezer (I will pinch him with a tweezer so that he burns).'

The therapist asks the quiet girl what she will do. 'She, she will run away,' Sandra quickly answers. The quiet girl, Jessame, answers slowly; 'I will burn him with a hot iron.'

Boiling water. A pan. A hot iron. A tweezer. A different take on the concept of domestic violence?

While the girls feistily explain how they will fight back, they are also aware that women tend to stay in violent relationships: some might be fighting back, but some might be suffering in silence.

Maria brings this up as a problem. 'On the TV then you see how the men beat their wives and the women do nothing, they keep quiet.'

The therapist asks why they think women remain silent about violence and do nothing.

Maria is clear. ' $W$ ant hulle is bang (because they are scared) ...'

Tara completes the sentence. '... bulle verloor die man (they lose the man).' With Simone adding, 'Bang... bulle liefde maak, bulle blind (their love makes them blind).'

Wise Maria states emphatically: 'Dis hoekom ek sê altyd liefde maak blind (that's why I always say that love makes you blind).' The other girls echo her.

Tara says, 'Miskien is sy nog baie lief vir die man en sy is nou bang om hom te verloor (maybe she still loves the man very much and she is also afraid to lose him).'

Simone adds, 'And sometimes the man threatens them ...'

They discuss a few examples of violence in vivid detail. Then they try to be wise again, understanding the acquiescence of the battered women.

'Die liefde (love)' Simone says resignedly.

'Tip,' Sandra say, 'Doesn't matter what he does they forgive them sommer easily.'

'He just gives her a soentjie (diminutive for kiss) then she is happy again.' This is Simone.

'Happy,' almost a chant from Maria.

Simone repeats, 'He kisses her.'

Well aware of the fact that women tend to stay in abusive relationships, the young women now turns to how dangerous men can be. ' $n$ Man kan jou lelik verongeluk, (a man can harm you in nasty ways)' says Sandra.

The therapist asks them how they feel when their mothers get beaten.

'Too much. It's just too much,' says Maria. 'Just don' beat my mom like that. That is just my mom. It's just my mom. No, no, no. It doesn't work like that.'

'We love them,' Sandra says. 'and we want to protect them.'

Some of the girls, however, feel that their mothers deserve to be beaten. 
Maria excitedly says, fist in the air, 'Then sometimes you say, "It's right. Beat her! Beat her! Beat her!|" Because she doesn't want to hear.'

'No, I never say that,' Sandra says.

Maria says, 'Your mom sometimes doesn't want to hear.'

Simone explains, 'Your mom now beat you now your dad comes now your dad beats your mom. Then you say, "It is right is right." She then beat me.'

'No,' says Sandra, 'I will say, "Daddy, leave mommy, It is right that she beats me."'

Thoughtful Sandra now suddenly turns to the group with a question: 'Now why when a man and a woman fights, you must now answer me nè, when a man and a woman fights, why does the child always take the mom's side and never the dad's?'

The group seriously engages with the question, talking over each other:

'We don't know,' Maria says, 'because the dad is often wrong.'

'Now say,' Sandra is persistent, 'the mother comes home drunk and say, klap (beats) the man all over the place and the man now beats the mom. Why do you always take the mom's side?'

Nee,' Simone says, 'because I say “No, mommy is wrong.'

Maria is adamant, 'No I sal saamklap (will join in with the hitting).' She thinks for a moment, then changes her mind. 'No I'll just sit there and watch and say, "Klap (Hit) maar each other, hit each other!"”

Sandra stays confused and says to the therapist. 'It's not true. They just say so. You always take the mom's side.' She stresses the always.

Simone has a different answer. 'Because you feel a mom cares more about you. A mom really cares more about you. A mom looks after you.'

The girls' animated conversation about their beaten up mothers is fraught with ambivalence: mother cares about you, mother takes care of you, your mother hits you, mommy is wrong, your dad hits your mother, that's right. Implicit in this conversation is a very familiar story, that caring can be cruel and violent and that mothers are both loved and hated. This story is not only one that we often hear in the valley, it is also a dominant story in psychoanalytic developmental theory ${ }^{59}$ and feminist psychoanalytic theory - the inevitability of the murder of the mother.

Much has been written about the conflict between love and hate, specifically the love-hate relationship children have with their carers. Girls typically have very strong and intense bonds with their mother, but these bonds are often characterised by conflict, anger, rage and fury. ${ }^{60}$ The struggle with the mother is often articulated by girls and women as a wish to be the opposite of their mothers: they are critical of their mothers, focus on the qualities of their mothers that they most dislike and struggle against showing any such qualities in themselves.

Feminist psychologists have written how in western culture "the mother's fall from grace" is the major source of anger in the mother-daughter relationship. ${ }^{61}$ While boys and girls typically are devastated when their mothers are devalued and treated with contempt, harshness

\footnotetext{
${ }^{59}$ Loewald's exposition of the development of the self...parricide as a necessary condition for the development of the self... an ambiguous process for both children and parents... It is what children strive to do, but when they do it, they feel guilty about it. Parents promote this destruction but resist it at the same time. The only successful way in which a child can go through this inevitable process is if he/she acknowledges the guilt, bears its burden and therefore masters it. Without the guilty deed of parricide there is no autonomous self. (S. Loewald, "The waning of the Oedipus complex," in Papers on Psychoanalysis (New Haven: Yale University Press, 1978): 384-403)

${ }^{60}$ Irene P. Stiver, "Beyond the Oedipus Complex: Mothers and Daughters," in Women's Growth in Connection: Writings from the Stone Center (New York \& London: The Guilford Press, 1991): 97-121.

${ }^{61}$ I.P Stiver, 1988: 110.
} 
and cruelty, for girls this is a double blow: their attachment to their mother is also identification - this is the person who they are going to become. The devaluation of the mother necessarily also implies their own devaluation.

Marguerite Duras, in her novel, The Lover, talks about the metaphorical murder of the mother in contemporary society:

We're united in a fundamental shame at having to live. It's here we are at the heart of our common fate, the fact that [we] are our mothers'children, the children of a candid creature murdered by society. We're on the side of society which has reduced her to despair. Because of what's been done to our mother.....we hate life, we hate ourselves. ${ }^{62}$

Adrienne Rich introduces the term "matrophobia" and claims that all daughters perform radical surgery to get rid of the victim mother in themselves:

Matrophobia can be seen as a womanly splitting of the self in the desire to become purged once and for all of our mother's bondage, to become individuated and free. The mother stands for the victim in ourselves, the unfree woman, the martyr. Our personalities seem dangerously to blur and overlap with our mothers; and in a desperate attempt to know where mother ends and daughter begins, we perform radical surgery. ${ }^{63}$

For women in western culture their mothers represent powerlessness, regression, passivity and dependence. ${ }^{64}$ Interestingly enough, while the girls in this group talk about how their battered mothers are powerless to leave, weak in their dependence, they also present their mothers as fighters, as being violent, aggressive and often intrusive. Similarly many of the adult women we work with are diagnosed with depression and link their distress as adult women to their relationships with their mothers, relationships characterised by intensity, but often also by anger and violence.

Corrie is a 62-year old pensioner and still remembers the hidings she got from her mother, with the imperative to be silent: 'I knew that if I cried, mom gave me a hiding and I would cry more. I mustn't talk back or I will get hit... they were very strict... It was very bad... Then she would say, "You hold your mouth now!" Now my pain becomes worse, now I must bury it because I will still get more hidings if I carry on. Now this is all stuff that I have held back inside'. Corrie starts crying and says; '... for all these years.... that dark blood in the rooms of my heart.'

Kristeva in the valley?

Kristeva writes how girls and women desperately try to identify with their powerful fathers, but when they become mothers they inevitably reconnect with their mothers and become them:

For a woman, the call of the mother...troubles the word: it generates hallucinations, voice, "madness"...It is a fragile envelope, incapable of staving off the irruption of this conflict, of the love which had bound the little girl to her mother, and which then, like black lava, had lain in wait for her all along the path of her desperate attempts to identify with the symbolic paternal order. ${ }^{65}$

Strikingly, many of the women explicitly articulate, how they don't want to be like their mothers. For example, Liza says, 'I want to have an open relationship with him [my son]. I want to give him what I didn't have. So I want to be a better parent than what my parents

${ }^{62}$ Marguerite. Duras, The Lover (Pantheon Books, 1985), https://www.amazon.com/Lover-MargueriteDuras/dp/0375700528.

${ }^{63}$ Rich, Of Woman Born: Motherbood as Experience and Institution, 165.

${ }^{64} \mathrm{~N}$ Chodorow, "Gender as a Personal and Social Construct," Signs: Journal of Women in Culture and Society Spring (1995): 516-44.

${ }^{65}$ Kristeva as cited in Alice Elaine Adams, Reproducing the Womb: Images of Childbirth in Science, Feminist Theory, and Literature (Ithaca \& London: Cornell University Press, 1994), 48. 
could be for me.' Dabbie echoes this sentiment, 'Yes, I don't want what happened between my mother and me to happen again between my daughter and me.'

It is clear that the violence in their households and the subsequent hurting and humiliation of their mothers disturbs the girls deeply and they talk about how they literally try to block their ears and put blankets over their heads so as not hear the fighting. They now talk over each other.

'I won't say anything I'll put my earphones in my ears and when they skel. Then I maar listen like that. O jinne (Oh geez), I can't take it.'

'When our people almost always skel in our house like that then I'm busy with my phone. Or I pull the blankets over my head and I cover my ears.'

'I cry, jong (man) that time.'

'I when I pull down the blankets then, I'll now hear the one now beating the other. Hear one of the kids crying. Their clothes full of snot as they cry.'

'Now I want to say. Just say someone now fights, my mom and my dad now fight, now just say I know and I hear them skel? I switch the TV on very loud and then I watch TV.'

The girls are clear, however, that there are dangers in not being aware of what is going on.

'While you are here in another world, then your mom lies dead.'

The ensuing discussion about what can happen during a fight is heart-breaking:

'No,' says Sandra,' my dad won't go that far.'

'Oh yes', says another one,' my dad will.'

A third one says, 'You don't know, your pa will. They will do it. If the ma makes the $p a$ angry dan sal by daai ma doodslaan (he'll beat that mother to death).'

Sandra, the girl who is clear that her father won't kill her mother, makes a little speech. 'I always say, one day I want a husband like my dad. He never beats my mom and if they argue they are okay again with each other later. And if they argue I know mos he won't beat her because he's not like that I want a husband like my dad. My mom said in the church the minister said a girl must say she wants a husband like her dad and a boy must say he wants a wife like his mom. My dad does not beat me. He works hard. In the sun. My dad is a builder"

Not everyone is as lucky. One of the girls describes her very violent father and how her emotions shift during the violent fights, 'My dad, I don't want to call him dad, almost everyone knows him, they know my dad is a strong man. If my mom and dad skel, I get a little tear and it is a bang traantjie (scared little tear). Because when my dad starts with her, by sal mens lewvendig in die grond in doodklap (he will beat her to death, into the ground while she is alive). And then I think o jirre (oh God), he is going to kill that woman. And it will take like a whole army to get my dad calm again because he's too on it, too in it. She makes him very angry and sometimes then kry ek ook lekker (it also gives me pleasure), then I think beat her beat her beat her. My cousin says my dad's hands must be chopped off if he beats my mom like that. I say if he kills her, ek maak hom net daar vrek (I'll kill him dead just there).

I will kill him dead just there. She is thirteen years old, school uniform adorned with a class captain badge.

The mood in the group is sombre now, the feistiness has been subdued. In the conversation there is the clear wish not to hear and not to be exposed to the violent love they inadvertently have to witness. There is the profound ambivalence: the terrible fear that the caring mother will be murdered if there is no vigilance, the longing to protect the mother and to take away the power of the father: ' $m y$ pa se hande moet afgekap word... (my dad's hands must be chopped off).' Always present, however, is the hate for the mother and the feelings of complicity with the murderer: 'dan kry ek ook lekker dan dink ek slaan haar, slaan haar (it also gives me pleasure then I think beat her beat her beat her).'

Sandra, the girl with the good father (the father who works hard in the sun) starts to collect the cups in which coke was served. She puts the screw top on the almost empty bottle 
and tightens it, her lips pursed. 'Dis nou soos 'n begrafnis hier (it's like a funeral here now)', she says.

The other girls giggle and put the remaining muffins in their jacket pockets.

The therapists pack up the crayons and the dream sheets, throw out the empty coke bottles and leave. The quiet girl's dream sheet lies on top of the pile in the back of the car. She dreams of becoming a lawyer, her mother is a domestic worker. 'My biggest dream is that my mom and my mom's children live alone on an island in a big house. We must be rich. We must be a happy family.'

The dark blood of the rooms of the heart. Black lava. The call of the mother. 